ANNA STAWARSKA-RIPPEL (Katowice)

\title{
Kontradyktoryjność i inkwizycyjność w europejskiej procedurze cywilnej XIX i XX wieku
}

I. Dziewiętnastowieczne tendencje społeczne, skutkujące potrzebą określenia obszarów prawa prywatnego i prawa publicznego na nowo ${ }^{1}$, spowodowały pogłębienie dylematów dotyczących celu procesu cywilnego. Ścieranie się poglądów dotyczących istoty procedury cywilnej występuje niemal od samych początków kształtowania się doktryny nowożytnego postępowania cywilne$\mathrm{go}^{2}$. W doktrynie ten cel zazwyczaj określa się, przyjmując kryterium interesu: czy proces cywilny służy interesom przede wszystkim prywatnym czy publicznym. Na trudność, a nawet niemożliwość odróżnienia i oddzielenia interesów prywatnych od publicznych wskazywano w teorii prawa od dawna ${ }^{3}$. Problemy o fundamentalnym znaczeniu wynikają ze szczególnego charakteru tej gałęzi prawa, znajdującej się na pograniczu prawa prywatnego i publicznego ${ }^{4}$.

Celem procesu cywilnego - pisał F.K. Fierich - jest zapewnienie sprawiedliwego orzecznictwa, a więc zgodnego z rzeczywistym stanem rzeczy i z obowiązującym prawem. Proces cywilny powinien jednocześnie zdążać do najszybszego uzyskania tytułu egzekucyjnego. Ekonomia procesowa wymaga, aby osiągnąć wspomniany cel najmniejszym nakładem kosztów i pracy stron oraz sądu ${ }^{5}$. Realizacja tych postulatów, rozstrzygnięcie kolizji zasad w kie-

${ }^{1}$ K. Sójka-Zielińska, Wielkie kodyfikacje cywilne. Historia i wspótczesność, Warszawa 2009, s. 222-223; eadem, Historia prawa, Warszawa 2003, s. 334-345; eadem, Kodeks Napoleona. Historia i wspótczesność, Warszawa 2007, s. 123-127; eadem, Drogi i bezdroża prawa, Wrocław-Warszawa-Kraków 2000, s. 64; eadem, Jednostka wobec państwa $w$ tradycjach kultury politycznoprawnej Zachodu, [w:] Przez tysiąclecia: państwo - prawo-jednostka, t. I, pod red. A. Lityńskiego i M. Mikołajczyka, Katowice 2001, s. 23.

${ }^{2} \mathrm{~K}$. Lutostański, $Z$ badań nad pierwiastkiem prywatnym i publicznym $w$ procesie cywilnym, Warszawa, 1907.

${ }^{3}$ J. Nowacki, Prawo publiczne - prawo prywatne, Katowice 1992, s. 16 i nast.

${ }^{4}$ Z. Resich, J. Lapierre, Jerzy Jodlowski. Człowiek i działalność, „Studia Iuridica” 1976, t. V, s. 11.

${ }^{5}$ F.K. Fierich, Postępowanie przed sadami okręgowymi. Uwagi ogólne. Rzut oka na strukturę najważniejszych procedur cywilnych, [w:] Polska Procedura Cywilna. Projekty referentów z uzasadnieniem. Przedruk wyczerpanych druków z r. 1921 i 1923, t. I, Warszawa 1928, t. I, s. 187. 
runku ich odpowiedniego wyważenia, pozostaje po dzień dzisiejszy podstawowym zamierzeniem reformatorów postępowania cywilnego. Nie tylko od litery prawa, ale też od „mądrości” samego sędziego zależy urzeczywistnianie celu procesu cywilnego, „co w rzeczywistości się staje, o tym osądzają ci, którzy tego prawa używają, sędziowie i adwokaci. Od nich zależy, czy ziarno wzejdzie"6. To „sędzia jest sternikiem, kierującym nawą sprawiedliwości”7.

Przenikanie się na gruncie procedury cywilnej interesu prywatnego i publicznego wiąże się ze współistnieniem zasady kontradyktoryjnej i zasady śledczej w postępowaniu. Zakres uwzględnienia tych zasad zależy od ideologicznego spojrzenia na relację między jednostką a społeczeństwem, interesem indywidualnym i dobrem społecznym.

Pojawienie się w Europie reżimów totalitarnych spowodowało zaburzenie ewolucji kształtowania się tej relacji. W zakresie procedury cywilnej totalitaryzmy nie akceptowały elementów prywatnoprawnych w postępowaniu, jako z istoty swej służącego ochronie prywatnych interesów jednostek. Prawa prywatne $w$ totalitaryzmach były jedynie relatywnie prywatne ${ }^{8}$. Po drugiej wojnie światowej, kraje Europy Środkowej stanęły przed problemem odrzucenia dotychczasowej tradycji prawnej na rzecz ,postępu socjalistycznego". W nauce prawa porównawczego pojawiły się poglądy o potrzebie wyodrębnienia trzeciej rodziny prawa - prawa socjalistycznego ${ }^{9}$.

II. Po upadku bloku radzieckiego wyróżnianie rodziny prawa socjalistycznego, obok dwóch podstawowych rodzin civil law i common law ${ }^{10}$, budzi zasadnicze wątpliwości w nauce prawa porównawczego ${ }^{11}$. Jeszcze przed rozwiązaniem ZSRR zachodni komparatyści nie byli zgodni nawet co do tego, czy socjalistyczne prawo uformowało się jako odrębna rodzina od civil law ${ }^{12}$, czy jako element lub podgatunek, czy też podrodzaj rodziny civil law ${ }^{13}$, albo

${ }^{6}$ F. Klein, Pro Futuro. Betrachtungen über Probleme der Zivilprozessreform in Oesterreich, Leipzig-Vienna, 1891, s. 6.

${ }^{7}$ F.K. Fierich, Wspótczesne zadania sędziego cywilnego a kwestia organizacji sądów ze szczególnym uwzględnieniem stosunków austriackich, „Themis Polska” 1913, s. 5.

${ }^{8}$ A. Lityński, O kodyfikacji procedury cywilnej w Polsce Ludowej, [w:] Ustrój i prawo w przeszłości dalszej i bliższej. Studia historyczne o prawie dedykowane Prof. Stanisławowi Grodziskiemu w pięćdziesiąta rocznicę pracy naukowej. Red. J. Malec, W. Uruszczak, Kraków 2001, s. 537; A. Lityński, Prawo Rosji i ZSRR 1917-1991, czyli historia wszechzwiąkowego komunistycznego prawa (bolszewików). Krótki kurs, Warszawa 2010, s. 15, 198 i nast.

${ }^{9}$ U. Mattei, Comparative Law and Economics, Michigan 1998, s. 203.

${ }^{10}$ R. David, J.E.C. Brierley, Major Legal Systems in the World Today, London 1968, s. 9-20.

${ }^{11}$ U. Mattei, Comparative Law..., s. 203.

${ }^{12}$ Wyodrębnienie jako trzeciej rodziny prawa, prawa socjalistycznego, postulowali: R. David, J. Hazard, J.H. Merryman, M. Ancel, Ch. Osakwe, M. Bogden i L.J. Constantinesco. Zob. P. De Cruz, Comparative Law in a Changing World, London-Sydney 1999, s. 186.

${ }^{13}$ Zwolennicy traktowania prawa socjalistycznego jako członu rodziny prawa civil law to: L. Friedman, F.H. Lawson, M.G. Losano, A.A. Ehrenzweig. Zob. P. De Cruz, Comparative Law in 
czy w ogóle powinno być wyodrębniane, ze względu na „nieistnienie głębi spowodowanej niezaprzeczalnym brakiem dojrzałości"14. Poglądy o oryginalnym i zarazem unikatowym charakterze radzieckiego, a także rosyjskiego prawa, w szczególności na tle postępowania cywilnego, wystąpiły tylko w doktrynie rosyjskiej ${ }^{15}$.

Po rozpadzie ZSRR i bloku komunistycznego pojawiły się postulaty zreklasyfikowania post-socjalistycznego systemu ${ }^{16}$. Znawcy przedmiotu dostrzegają jednak problemy takiej reklasyfikacji ze względu na zróżnicowanie wpływu elementów socjalistycznego modelu, ich kontynuacji i zmian we współczesnym prawie państw Europy Wschodniej i Środkowej. Przed sowietyzacją Europa Środkowa jak również Wschodnia były pod głębokim wpływem systemu romańsko-germańskiego. Państwa Europy Środkowej charakteryzowały się wysoko rozwiniętą kulturą prawną i przez wieki funkcjonowały w ramach głównego nurtu zachodniej tradycji prawnej, w przeciwieństwie do wielu krajów wchodzących w skład byłego ZSRR ${ }^{17}$.

Pewne tendencje rozwoju w zakresie prawa procesu cywilnego wydają się zbieżne bez względu na poglądy dotyczące wyróżniania i przynależności do danej rodziny prawa ${ }^{18}$, a także różnice pomiędzy nimi wynikające $\mathrm{z}$ odmiennych tradycji ${ }^{19}$.

III. W kręgu civil law, macierzysta dla wszystkich nowożytnych kodeksów postępowania cywilnego, francuska procedura cywilna, wpisała się w ogólny „tryumf realizmu nad utopią” całości dzieła napoleońskich kodyfikacji $^{20}$. Nazywana ,już starą, kiedy się urodziła" ${ }^{21}$, a zarazem doskonale ko-

a Changing World..., s. 186. Zob. też. R.L. Prosterman, T.M. Hanstad, Legal impediments to effective rural land relations in Eastern Europe, Washington 1999, s. 10.

${ }^{14}$ Cyt. za W.E. Butler, Soviet Law, London 1983, s. 1.

15 D. Maleshin, The Russian Style of Civil Procedure, „Emory International Law Review” 2007, vol. 21, s. 543-562; idem, The Russian Style of Civil Procedure, [w:] The Reception and Transmission of Civil Procedural Law in Global Society, ed. M. Deguchi, M. Storme, AntwerpenApeldoorn 2008, s. 311-320. Por. R. David, J.E.C. Brierley, Major Legal Systems in the World..., s. 58.

${ }^{16}$ U. Mattei, Comparative Law..., s. 203.

${ }^{17}$ Ibidem, s. 206.

${ }^{18}$ M.R. Damaska, The Faces of Justice and State Authority. A Comparative Approach to the Legal Process, New Haven-London 1986, s. 3.

${ }^{19}$ Encyclopedia of Comparative Law, vol. XVI Civil Procedure, ch. 1 Introduction - Policies, Trends and Ideas in Civil Procedure, ed. M. Cappelletti, B.G. Garth, Tübingen-Dordrecht-BostonLancaster 1988, s. 4.

${ }^{20}$ K. Sójka-Zielińska, Idee kodyfikacji napoleońskich. Od utopii do realizmu, „Czasopismo Prawno-Historyczne" 2005, t. LVII, z. 2, s. 27.

${ }^{21}$ L. Cadiet, The international sources of French civil procedure, [w:] The Reception and Transmission of Civil Procedural Law in the Global Society, ed. M. Deguchi, M. Storme, Antwerpen-Apeldoorn 2008, s. 263. Zob. też: R.C. van Caenegem, D.E.L. Johnston: An Historical Introduction to Private Law, Cambridge University Press, 1992, s. 91. 
respondująca z liberalnymi zasadami francuskiego kodeksu cywilnego, była jednak najmniej innowacyjnym dziełem napoleońskiej doby ${ }^{22}$. Dość szybko dostrzeżono wady tej kodyfikacji. Najwcześniej pisał o nich, w pośmiertnie opublikowanym dziele, jeden z autorów napoleońskiego kodeksu procedury cywilnej, Eustachy Nicolas Pigeau ${ }^{23}$. Sztywność przepisów napoleońskiej procedury francuskiej i jej nadmierny formalizm przeważały nad merytorycznymi względami sprawiedliwości rozstrzygnięcia. Szeroko uwzględniona zasada kontradyktoryjności powodowała $\mathrm{w}$ praktyce przewlekanie postępowania. Te wady dostrzegali również uczeni z Kongresówki, gdzie francuski kodeks postępowania cywilnego obowiązywał do 1876 r.: „Kodeks postępowania cywilnego miał redakcję mniej staranną, przeładowany był wyrazami technicznymi, niezrozumiałymi dla laików, oraz styl mniej jasny"24.

Doświadczenia wynikające z obowiązywania dość głęboko kontradyktoryjnej francuskiej procedury cywilnej, w powiązaniu z postępującym kryzysem liberalizmu i zjawiskiem publicyzacji prawa prywatnego, spowodowały potrzebę modyfikacji dotychczasowych założeń w zakresie procesu cywilnego. Kluczowym zagadnieniem rozważanym w nauce procesu cywilnego stał się zakres uwzględnienia w postępowaniu cywilnym zasad, zdefiniowanych po raz pierwszy przez Nikolausa Thaddäusa Gönnera $(1801)^{25}$, W szczególności zasady kontradyktoryjności (Verhandlungmaxime) i zasady śledczej (Untersuchungsmaxime). Uzupełnione nieco później o zasady dyspozycyjności (Disposittionsmaxime) i oficjalności (Offizialprinzip), tworzyły w teorii prawa dwa przeciwstawne systemy procesowe, dyspozycyjno-kontradyktoryjny i oficjalno-śledczy. Jednak w praktyce żaden z tych systemów procesowych nie został konsekwentnie zrealizowany w nowożytnym procesie cywilnym ${ }^{26}$.

Przełamanie dotychczasowego modelu francuskiego, opartego w zasadniczej mierze na zasadach dyspozycyjności i kontradyktoryjności przez pro-

22 C.H. Van Rhee, Introduction, [w:] European Traditions in Civil Procedure, ed. C.H. Van Rhee. Antwerpen-Oxford 2005, s. 6.

${ }^{23}$ Nicolas Pigeau (1750-1818). Jeden z autorów francuskiej procedury cywilnej (1806), profesor, adwokat, wykładał w l'Ecole de Droit de Paris. Pozostali twórcy francuskiego kodeksu procedury cywilnej to: Jean-Baptiste Treilhard (1742-1810), polityk, senator, hrabia, sędzia Trybunału Kasacyjnego, prezes sądu apelacyjnego; Antoine Jean Mathieu Seguier (1803-1848) baron, pierwszy prezes Trybunału Apelacyjnego w Paryżu; Thomas Berthereau (1733-1817), prezes Trybunału Cywilnego Departamentu Sekwany; Bertrand Try, komisarz rządowy. Zob. A. Engelmann, A History of Continental Civil Procedure. The Continental Legal History Series, vol. 7, transl. and ed. by R.W. Millar, Boston 1927, s. 750.

${ }^{24}$ B. Stelmachowski [w:] Encyklopedia prawa obowiazującego w Polsce, cz. 5, Zarys ustroju sadownictwa i postępowania cywilnego, pod red. A. Peretiatkowicza, Poznań 1926, s. 3.

${ }^{25}$ W. Berutowicz, Zasada dyspozycyjności w postępowaniu cywilnym, Warszawa 1957, s. 12.

${ }^{26}$ M. Waligórski, Gwarancje wykrycia prawdy w procesie cywilnym, „Państwo i Prawo” 1953, nr 8-9, s. 262; P. Rylski, Działanie sadu a podstawa faktyczna wyroku cywilnego, Warszawa 2009, s. 99. 
cedurę kleinowską ${ }^{27}$, wyznaczyło ostatecznie kierunek reform postępowania cywilnego w Europie ${ }^{28}$.

Wyjściowym założeniem Franza Kleina było uznanie, że każdy spór prawny jest negatywnym zjawiskiem społecznym, który wymaga prostej, szybkiej i taniej procedury cywilnej. Jego zdaniem tok postępowania cywilnego nie powinien być pozostawiony wyłącznej inicjatywie stron, ponieważ proces dotyczy społeczeństwa jako całości, stąd w postępowaniu cywilnym istotny jest także interes publiczny ${ }^{29}$. W swym programowym dziele (Pro Futuro, 1891) Klein wyraził pogląd, że aktywny w postępowaniu cywilnym sędzia będzie remedium na przewlekłe i kosztowne postępowanie. Sędzia miał tez dążyć do ustalenia prawdy materialnej, zamiast bazować na dowodach przedstawionych jedynie przez strony ${ }^{30}$.

W zakresie przyśpieszenia postępowania interesowały F. Kleina rozwiązania angielskiego postępowania sądowego, w szczególności regulacje dotyczące obrazy sądu, przeprowadzenia dowodu z przesłuchania stron oraz procedura przygotowania do rozprawy ${ }^{31}$.

Przewartościowanie celów postępowania cywilnego i uznanie publicznego charakteru postępowania cywilnego, samej procedury a nie praw cywilnych stron i przedmiotu procesu, skutkowało postulatem aktywnego wkraczania państwa w sferę postępowania cywilnego. Postępowanie cywilne zaczęto postrzegać jednocześnie w kontekście pełnienia ważnych funkcji społecznych (Sozialfunktion) i realizacji interesu publicznego (Wohlfahrtsfunktion) ${ }^{32}$.

Idee F. Kleina zapoczątkowały nowy etap w ewolucji postępowania cywilnego. Zmiany w procedurze cywilnej podążały w kierunku rozszerzenia zasady śledczej, zwiększenia wpływu sądu na przebieg postępowania, i gromadzenia dowodów, dopuszczenia udziału prokuratora w sprawach cywilnych (m.in. ze stosunków rodzinnych) oraz wprowadzenia obowiązku prawdomówności

${ }^{27}$ Austriacka procedura cywilna przełamała model dyspozycyjno-kontradyktoryjny w dwóch kierunkach. Po pierwsze - dochodzenie do prawdy nie było ograniczone do kwestii spornych sędzia był zobowiązany czynić odpowiednie starania celem wyczerpującego wyjaśnienia sprawy ( 180 austriackiej ustawy z 1 sierpnia 1895 r.), po drugie w postępowaniu dowodowym sąd nie musiał ograniczać się jedynie do dowodów przedstawionych przez strony ( $\$ 183$ austriackiej ustawy z 1 sierpnia 1895 r.).

${ }^{28} \mathrm{Na}$ modelu austriackim wzorowały się Niemcy, Węgry, Polska, Niderlandy, gdzie wcześniej występował wyraźny wpływ procedury francuskiej, co zaczęło ulegać zmianie w drugiej połowie XIX w., oraz Skandynawia, Grecja, Liechtenstein, Zurych, a także Francja w drugiej połowie XX w. Zob. C.H. van Rhee, Introduction..., s. 13.

${ }^{29}$ W.H. Rechberger, T. Klicka, Accelerating Civil Litigation in Austria in the Twentieth Century, [w:] The Law's Delay. Essays on Undue Delay in Civil Litigation. Ed. C.H. van Rhee, Antwerpen-Groningen 2004, s. 234.

${ }^{30}$ C.H. van Rhee, R. Verkerk, Civil Procedure, [w:] Elgar Encyclopedia of Comparative Law, ed. J.M. Smits, Cheltenham, Great Britain 2006, s. 123.

${ }^{31}$ C.H. van Rhee, Introduction..., s. 18-19.

${ }^{32}$ Ibidem, s. 11-12. 
(Wahrheitspflicht). Tym samym odchodzono w procesie cywilnym od tzw. prawdy formalnej na rzecz prawdy materialnej, inaczej zwanej obiektywną. Współcześnie zauważono, że postulaty F. Kleina są przydatne w reformowaniu postępowania cywilnego $\mathrm{w}$ większym zakresie obecnie niż ponad sto lat temu ${ }^{33}$. Najwcześniej i najpełniej zrealizowały te nowe postulaty węgierski kodeks procedury cywilnej z 1911 r. oraz kodeksy kantonów szwajcarskich, Zurychu (1913) i Berna (1918).

Efektem prac kodyfikacyjnych na Węgrzech podjętych po przemianach ustrojowych $1867 \mathrm{r}^{34}$ był kodeks postępowania cywilnego z $1911 \mathrm{r}^{35}$ zwany potocznie kodeksem Sándora Plósza ${ }^{36}$. Architektami węgierskiego kodeksu procedury cywilnej było dwóch wybitnych prawników: Sándor Plósz, wybitny jurysta, profesor, znawca niemieckiego prawa cywilnego procesowego, minister sprawiedliwości, i sędzia Kornel Emmer. Obaj eksperci z polecenia Ministerstwa Sprawiedliwości zdobywali doświadczenia za granicą - Sándor Plósz wizytował we Francji, Belgii, Szwajcarii i w Niemczech. Prowadził przede wszystkim studia nad praktyką w zakresie niemieckiej procedury cywilnej po wprowadzeniu w życie kodeksu z 1877 r. Jego badania nad funkcjonowaniem niemieckiego prawa cywilnego procesowego skutkowały tym, że Sándor Plósz był zwolennikiem recepcji niemieckich rozwiązań. Kornel Emmer był zainspirowany głównie Francją i tamtejszym modelem prawa cywilnego procesowego. Ostatecznie przeważyła koncepcja Sándora Plósza. Kodeks węgierski szeroko uwzględnił nowe tendencje w procedurze cywilnej, dając sędziemu silną pozycję i szeroką przestrzeń do kierowania postępowaniem, w szczególności do zbierania dowodów ex officio ${ }^{37}$. Bazując na rozwiązaniach niemieckiej i austriackiej procedury cywilnej, wnosił jednocześnie pewne nowości. W zakresie struktury procesu w pierwszej instancji oraz postępowania dowodowego ${ }^{38}$, „duch socjalny” i aktywność sędziego

${ }^{33}$ C.H. van Rhee, Introduction..., s. 11.

34 A. Dziadzio, Monarchia konstytucyjna w Austrii 1867-1914. Władza, obywatel, prawo, Kraków 2001, s. 9-27.

${ }^{35}$ 1911. évi I. törvénycikk a polgári perrendtartásról.

${ }^{36}$ I. Varga, Foreign Influences on Hungarian Civil Procedural Law, [w:] The Reception and Transmission of Civil Procedural Law in the Global Society. Legislative and Legal Educational Assistance to Other Countries in Procedural Law, ed. M. Deguchi, M. Strom, Antwerpen-Apeldoorn 2008, s. 277. Zob. też: A. Stawarska-Rippel, Węgierska procedura cywilna z $1911 \mathrm{r}$. w pracach sekcji postępowania cywilnego Komisji Kodyfikacyjnej II RP na przykladzie projektu Tytulu o dowodach J.J. Litauera, [w:] Państwo, prawo, społeczeństwo w dziejach Europy Środkowej, komitet red. M. Mikołajczyk, T. Adamczyk, A. Drogoń, W. Organiściak, Katowice-Kraków 2009, s. $645-661$.

${ }^{37}$ I. Varga, Foreign Influences on Hungarian Civil Procedural Law..., s. 287.

${ }^{38}$ Według procedury cywilnej węgierskiej (A polgári perrendtartásról 1911. évi I. törvénycikk - § 288) sąd mógł przeprowadzić dowody na które strony powołały się choćby w pismach przygotowawczych. Zob. też: A. Stawarska-Rippel, Węgierska procedura cywilna z $1911 \mathrm{r}$. w pracach sekcji postępowania cywilnego Komisji Kodyfikacyjnej II RP..., s. 651, 659. 
procedury kleinowskiej były jedynie sugestią do rozwinięcia tych zasad dla autorów kodeksu węgierskiego ${ }^{39}$.

Specyfika szwajcarskiego systemu prawnego, partykularyzm prawny powodowany rozległymi kompetencjami ustawodawczymi kantonów począwszy od $1815 \mathrm{r}$. i następnie utrzymanych konstytucją z $1848 \mathrm{r}^{40}$, uczyniły prawo szwajcarskie ważnym tematem dla komparatystów. Poczucie odrębności kulturowej, mimo wielokulturowości i podleganiu od wieków wpływowi państw ościennych ${ }^{41}$, czyniły Szwajcarię demokracją konsolidacyjną, konkordatową ${ }^{42}$, realizującą prawa mniejszości. W kantonach szwajcarskich począwszy od 1819 do 2001 r. wydano 92 kodeksy procedury cywilnej. W XIX w. starano się stworzyć podwaliny unifikacji i przekazania władzy ustawodawczej w zakresie procedury cywilnej Federacji, jednak bez rezultatu ${ }^{43}$. Pierwszy kodeks procedury cywilnej został wydany w Genewie (1819), w ciągu niespełna 6 lat po odzyskaniu niepodległości, zastępując francuski kodeks procedury cywilnej. Kodeks procedury cywilnej Genewy bazował na prawie francuskim, zachowując to, co postępowe, i eliminując słabości francuskiego kodeksu ${ }^{44}$. W niemieckojęzycznych kantonach pierwszym kodeksem procedury cywilnej, stanowiącym jednocześnie pewien model dla innych kantonów, był kodeks Zurychu ${ }^{45}$. Pozostawanie w dwóch zasadniczych strefach oddziaływania, prawa francuskiego i prawa niemiecko-austriackiego nie zdołało stłumić miejscowej tradycji. Kodeksy procedury cywilnej w większej mierze opierały się na dziedzictwie prawnym poszczególnych kantonów niż na prawie francuskim albo niemieckim ${ }^{46}$. Likwidację partykularyzmu Szwajcarii w zakresie procedury cywilnej przyniosły dopiero ostatnie lata ${ }^{47}$.

Kodeksy procedury cywilnej kantonów szwajcarskich Zurychu (1913) ${ }^{48}$ i Berna $(1918)^{49}$ przewidywały znaczne rozszerzenie uprawnień sądu, w duchu socjalizacji. Aktywna rola sędziego w procesie wyrażała się przede

${ }^{39}$ I. Varga, Foreign Influences on Hungarian Civil Procedural Law..., s. 287.

${ }^{40}$ K. Sójka-Zielińska, Stulecie kodeksu cywilnego szwajcarskiego, „Czasopismo Prawno-Historyczne", 2012, t. LXIV, z. 2, s. 29.

${ }^{41}$ Ibidem.

${ }^{42}$ A. Porębski, Wielokulturowość Szwajcarii na rozdrożu, wyd. WUJ, Kraków 2010, s. 212.

${ }^{43}$ K. Sójka-Zielińska, Stulecie kodeksu cywilnego szwajcarskiego..., s. 40; P. Oberhammer, T. Domej, Germany, Switzerland, Austria (ca. 1800-2005), [w:] European Traditions in Civil Procedure..., s. 125-126.

${ }^{44}$ P. Oberhammer, T. Domej, Germany, Switzerland, Austria..., s. 124.

${ }^{45}$ Ibidem, s. 125.

${ }^{46}$ Ibidem.

${ }^{47}$ Pierwszy jednolity szwajcarski kodeks postępowania cywilnego - Schweizerische Zivilprozessordnung (Zivilprozessordnung, ZPO) został uchwalony 19 grudnia 2008 r., zastępując kodeksy procedury cywilnej 26 kantonów.

${ }^{48}$ Gesetz betreffend den Zivilprozess (Zivilprozessordnung) vom 13. April 1913 mit den seitherigen Änderungen, wyd. wznowione w 1951 r., bez miejsca wydania.

${ }^{49}$ Die Zivilprozessordnung für den Kanton Bern z 7 lipca 1918 r. 
wszystkim w możliwości ingerencji sędziego w przebieg postępowania, w szczególności w obowiązku wyjaśnienia sprawy i uzupełnienia niejasnych twierdzeń stron oraz możliwości powoływania dowodów niezawnioskowanych przez strony ${ }^{50}$. Te tendencje zostały zachowane w jednolitym kodeksie szwajcarskim $^{51}$.

Węgierski kodeks procedury cywilnej (1911) oraz kodeksy kantonów Berna (1918) i Zurychu (1913) zostały docenione również przez członków sekcji postępowania cywilnego Komisji Kodyfikacyjnej Drugiej Rzeczypospolitej. Szczególną uwagę tym najnowszym ówcześnie kodeksom postępowania cywilnego poświęcili Józef Skąpski, Franciszek Ksawery Fierich i Jan Jakub Litauer.

J. Skąpski podkreślał ,wysokie zasady etyki procesowej nowej procedury kantonu zuryskiego". Doceniał zwłaszcza regulację § 90 tego kodeksu, który zakazywał stronom wdrażania świadomie niesłusznych procesów i dochodzenia swych praw za pomocą niedozwolonych środków, ustanawiając równocześnie obowiązek prawdomówności oraz karę dyscyplinarną za prowadzenie sporów w złej wierze. J. Skąpski postulował, by w polskim kodeksie procedury cywilnej uwzględnić ,najdalej idące rozszerzenie ustawowych pełnomocnictw sędziego" "52. Doceniał też systematykę kodeksu berneńskiego:

„Z nowszych ustawodawstw wielką zaletą co do układu zewnętrznego odznacza się procedura szwajcarska dla kantonu berneńskiego z 7-go lipca 1918. W stu kilkudziesięciu artykułach wstępnych ujmuje kodyfikacja ta wszystkie urządzenia natury ogólnej, a zaleta takiego układu polega na tym, że wobec wspólnej części ogólnej przy dalszych rozdziałach odpadają wszystkie postanowienia ogólne jeden nawias dla wszystkich rozdziałów".

F.K. Fierich uważał, że „należy jednakże poświęcić słów kilka procedurze węgierskiej, tak ze względu na pewną - aczkolwiek w małych rozmiarach - aktualność dla naszej Ojczyzny jako też ze względu, że jest ona jed-

${ }^{50}$ Die Zivilprozessordnung für den Kanton Bern z 7 lipca 1918 r. - art. 214: „Beweismittelbeiziehung durch den Richter Der Richter kann Beweismittel heranziehen, welche von den Parteien nicht angerufen sind. Er entscheidet, welche Partei in diesem Falle die für die Durchführung notwendigen Kosten vorzuschiessen hat"; Die Zivilprozessordnung für den Kanton Zürich z 13 kwietnia 1913 r. $-\S 166$ : Der Richter kann ausnahmsweise auch von Amtes wegen Beweise abnehmen, welche die Parteien nicht speziell anerboten haben, sofern sich aus den Akten Anhaltspunkte ergeben, dass dadurch die Feststellung des wahren Sachverhalts gefördert wird. Die Beweisabnahme hat aber zu unterbleiben, wenn die beweispflichtige Partei darauf verzichtet oder in unentschuldbarer Weise innert angesetzter First für die entstehenden Barauslagen keinen Vorschuss geleistet hat".

${ }^{51}$ P. Rylski, Działanie sadu a podstawa faktyczna wyroku cywilnego, Warszawa 2009, s. 135-136; P. Oberhammer, T. Domej, Germany, Switzerland and Austria: Power of the Judge, [w:] European Traditions in Civil Procedure..., s. 299-300.

52 J. Skąpski, [w:] Polska Procedura Cywilna..., t. I, s. 168. 
ną z najnowocześniejszych i najwybitniejszych procedur cywilnych państw kulturalnych"53. J.J. Litauer w swoim projekcie Tytulu o dowodach w 34 przypadkach na 93 artykuły projektu wzorował się wyłącznie na cywilnej procedurze berneńskiej i węgierskiej ${ }^{54}$.

Członkowie sekcji postępowania cywilnego Komisji Kodyfikacyjnej II RP, sięgając do rozwiązań najnowocześniejszych wówczas kodeksów procedury cywilnej, byli świadomi, że z doniosłym zadaniem kodyfikacji prawa wiązała się potrzeba poznawania nowych tendencji w procedurze cywilnej oraz osiągnięć europejskiej komparatystyki. Ostatecznie jednak sekcja postępowania cywilnego KK II RP zdecydowała o przyjęciu rozwiązania kompromisowego na wzór austriacki, by nie czynić ,gwałtownych przeskoków i nie wprowadzać radykalnych nowości, wychodząc z założenia, że życie prawne nie może być terenem dla doktrynalnych doświadczeń" 55 .

Nowelizacje niemieckiego kodeksu procedury cywilnej z 1877 r. podejmowane w latach 1924-1933, w kontekście wydarzeń historycznych i uwarunkowań ustrojowo-politycznych, postrzegane są jako powodowane ówczesną ideologią ${ }^{56}$. W rzeczywistości, nowelizacja niemieckiej procedury cywilnej z 1933 r. bazowała na rozwiązaniach proponowanych we wcześniejszym projekcie z 1931 r., którego celem było zharmonizowanie prawa austriackiego i niemieckiego w zakresie postępowania cywilnego ${ }^{57}$. Nowela z 1933 r. nie odbiegała zasadniczo od ogólnej tendencji zmian w procedurze cywilnej innych krajów Europy. Sędzia miał obowiązek wszechstronnego wyjaśnienia wszystkich okoliczności faktycznych i dbania o to, by strony przedstawiały dowody na poparcie swoich twierdzeń. Strony miały obowiązek składać wyjaśnienia wyczerpująco i zgodnie z prawdą ${ }^{58}$.

We Włoszech, obowiązujący kodeks postępowania cywilnego (1865), wzorowany na francuskiej procedurze cywilnej, już z początkiem XX w. uchodził za przestarzały. Projekty reformy procedury cywilnej z lat 1920-1937, nawiązujące w dużej mierze do regulacji niemieckich, nie przyniosły efektu w postaci nowej kodyfikacji przed II wojną światową. Toczona ówcześnie we Włoszech ożywiona dyskusja nad procedurą cywilną odbiła się szerokim echem w Europie. Nauka włoska dotycząca procesu cywilnego

${ }^{53}$ F.K. Fierich, [w:] Polska Procedura Cywilna..., t. I, s. 198.

${ }^{54}$ J.J. Litauer, [w:] Polska Procedura Cywilna..., t. I, s. 265-299.

${ }^{55}$ S. Gołąb, Projekty polskiej procedury cywilnej. Powstanie - uzasadnienie - zdania odrębne, Kraków 1930, s. 41.

${ }^{56}$ S. Płaza, Historia prawa w Polsce na tle porównawczym. Cz. 3. Okres międzywojenny, Kraków 2001, s. 485-486; J. Klich-Rump, Podstawa faktyczna rozstrzygnięcia sądowego $w$ procesie cywilnym, Warszawa 1977, s. 65.

${ }^{57}$ P. Oberhammer, T. Domej, Germany, Switzerland and Austria (ca. 1800-2005), [w:] European Traditions in Civil Procedure, ed. C.H. Van Rhee, Antwerpen-Oxford 2005, s. 114.

${ }^{58}$ J. Klich-Rump, Podstawa faktyczna rozstrzygnięcia sadowego w procesie cywilnym..., s. 65. 
została uznana za bezwzględnie przodującą ${ }^{59}$. Tam też postulował unifikację prawa procesowego w Europie wybitny prawnik włoski Emilio Betti ${ }^{60}$.

Zarówno rozwiązania niemieckie (do 1933 r.) jak i włoskie, mimo znacznego uwzględnienia pierwiastka publicznego w procedurze cywilnej nie przekreślały istoty tego procesu, jako służącego ochronie interesów prywatnych zgodnie z zasadami ne procedat iudex ex officio i ne eat iudex ultra petita partium.

Ewolucyjnemu ograniczaniu autonomii stron i tendencji uwzględniania w większej mierze elementów śledczych, celem osiągnięcia takich wartości, jak zapewnienie rzetelnego i sprawiedliwego rozstrzygnięcia $\mathrm{w}$ szybkim i zarazem ekonomicznie korzystnym procesie cywilnym, poddała się również Francja (1975). Podczas gdy na pierwszym francuskim kodeksie procedury cywilnej wzorowali się zarówno Niemcy jak i Włosi, to drugi francuski kodeks procedury cywilnej ${ }^{61}$ pozostawał już pod wpływem nowych rozwiązań w nauce niemieckiej i włoskiej, głównie za przyczyną dwóch znakomitych prawników Henry'ego Motulsky'ego i Henry'ego Vizioza ${ }^{62}$.

Kodeks postępowania cywilnego z 1975 r. przyjął rozwiązania plasujące procedurę pomiędzy kontradyktoryjną a inkwizycyjną, wyrażające się we współpracy sądu, adwokatów i radców prawnych - pełnomocników, dla pożytku stron. Sąd ma możliwość aktywnego uczestnictwa w zakresie ustalania

${ }^{59}$ M. Waligórski, Polskie prawo procesowe cywilne. Funkcja i struktura procesu, Warszawa 1947, s. 26-27; S. Płaza, Historia prawa w Polsce na tle porównawczym..., s. 492-493; M. Cappelletti, J.H. Merryman, J.M. Perillo, The Italian Legal System, Stanford University Press 1967, s. 50-51. Zob. też: C. Calisse, History of Italian Law, vol. II, Washington 2001, s. 791-792.

${ }^{60}$ Emilio Betti - włoski jurysta, wybitny znawca prawa rzymskiego i procedury cywilnej. Równocześnie teolog i filozof, autor ok. 300 prac naukowych Jego zainteresowania oscylowały przede wszystkim wokół problemów związanych z wykładnią. Był twórcą jednego z kanonów hermeneutyki prawniczej, przedstawicielem jej metodologicznego nurtu. Najbardziej znaną pracą E. Bettiego z zakresu procedury cywilnej jest Diritto Processuale Civile Italiano, Roma 1935 (wyd. I), 1936 (wyd. II). O nauce włoskiej procesu cywilnego po I wojnie światowej zob. M. Waligórski, Polskie prawo procesowe cywilne..., s. 26-27. Zob. też biografia E. Bettiego: M. Ciocchetti, „Emilio Betti” - Giureconsulto e umanista, Belforte del Chienti 1998; E. Betti, Teoria generale della interpretazione, Instituto di Teoria della Interpretazione. Millano 1955. Wyd. w przekładzie na język niemiecki: Allgemeine Auslegungslehre als Methodik der Geisteswissenschaften, Tübingen 1967. Zob. też: J. Stelmach, R. Sarkowicz, Filozofia prawa XIX i XX wieku, Kraków 1998, s. 122, 126-127.

${ }^{61}$ Zdaniem niektórych autorów zmiany ustrojowe wprowadzone konstytucją z 28 września 1958 r., wzmacniające władzę wykonawczą, przyspieszyły reformę francuskiej procedury cywilnej - nowele do procedury cywilnej przed uchwaleniem nowego kodeksu wprowadzane były na mocy rządowych dekretów z mocą ustawy. C.H. Van Rhee, Introduction..., s. 13.

${ }^{62}$ Henry Motulsky (1905-1971) - niemiecki uczony pochodzenia żydowskiego, prawnik praktykujący w Niemczech. Gdy w nazistowskich Niemczech wykluczono od wszelkiej działalności naukowej uczonych pochodzenia żydowskiego, schronił się przed reżimem we Francji. Uznany, obok Jeana Foyer i Gerarda Cornu, za „ojca” francuskiego kodeksu procedury cywilnej z 1975 r.; Henry Vizioz (1886-1948) - znawca i propagator nauki włoskiej we Francji. L. Cadiet, The International Sources of French Civil Procedure, [w:] The Reception and Transmission of Civil Procedural Law in the Global Society..., s. 267. 
podstawy faktycznej, zarówno w sferze twierdzeń faktycznych stron, jak i powoływania oraz przeprowadzania dowodów. W uzasadnieniu pierwszego projektu nowego francuskiego kodeksu postępowania cywilnego sformułowano zasadnicze cele reformy następująco:

„Ich [Komisji - A. S.-R.] praca jest rezultatem głębokiego studium, które nie ograniczało się do orzecznictwa wypracowanego na podstawie już bardzo przestarzałego kodeksu [...] Ich osiągnięciem było to, że bez zburzenia starego gmachu było możliwe zmienić jego wewnętrzne urządzenie wprowadzić do niego powietrze tego wieku w ten sposób, że odbywając się nadal w zwykłych ramach wypróbowanych przez pokolenia praktyków dostęp do sędziego stał się mniej uciążliwy, tok procesu mniej powolny i sędzia lepiej poinformowany. Te zasadnicze cele praktyczne ożywiają projekt nowego kodeksu postępowania cywilnego. Nawet dzieło niedoskonałe, które w tych czasach może się pochwalić takimi koncepcjami, jest wartościowe"63.

III. W kręgu common law zasadniczy przełom (1999) w postępowaniu sądowym w sprawach cywilnych w Anglii, najbardziej charakterystycznym dla tej rodziny prawa, miał na celu zapewnienie sprawności procedury oraz umożliwienia sądowi sprawiedliwego prowadzenia postępowania ${ }^{64}$. Mimo przeprowadzanych reform, począwszy od The Judicature Acts (1873-1875), proces cywilny w Anglii był postrzegany jako przewlekły, skomplikowany i kosztowny oraz kazuistyczny ${ }^{65}$. W 1994 r. zdecydowano po raz kolejny podjąć prace nad rewizją postępowania cywilnego. Celem reformy miało być przyspieszenie postępowania cywilnego, uproszczenie procedury, uczynienie jej bardziej dostępną dla obywateli i przedsiębiorców oraz propagowanie dążności ugodowych ${ }^{66}$. Lord Harry Woolf, autor reformy, sformułował główne jej założenie jako ,zasadnicze przeniesienie odpowiedzialności kierowania w sprawach cywilnych ze stron i ich pełnomocników na sąd"67. Sędzia miał nadzorować postępowanie przed rozprawą (pre-trail watch-dog) i dbać o sprawność postępowania (time-keeper). Zakres materialnego kierownictwa sędziego miał być dostosowany indywidualnie do każdej sprawy, w zależno-

${ }^{63}$ Tekst projektu francuskiego kodeksu postępowania cywilnego (1954) z uzasadnieniem pochodzi z materiałów Komisji Kodyfikacyjnej opracowującej kodeks postępowania cywilnego PRL. AAN, MS, sygn. 2228, k. 33-35. Projekt francuskiego kodeksu postępowania cywilnego z $1954 \mathrm{r}$. był pierwszą próbą reformy, której końcowy etap przypadał już na lata 1971-1975. A. Wijffels, French Civil Procedure (1806-1975), [w:] European Traditions in Civil Procedure..., s. 42-44.

${ }^{64}$ Cyt. za P. Rylski, Działanie sądu z urzędu..., s. 145.

${ }^{65}$ P. Rylski, Dziatanie sadu z urzędu..., s. 144; C.H. van Rhee, English Civil Procedure until the Civil Procedure Rules (1998), [w:] European Traditions in Civil Procedure..., s. 146-160; N. Andrews, The New English Civil Procedure Rules (1998), [w:] European Traditions in Civil Procedure..., s. 166-167.

${ }^{66}$ N. Andrews, The New English Civil Procedure Rules..., s. 166.

${ }^{67}$ Cyt. za: N. Andrews, The New English Civil Procedure Rules..., s. 167. 
ści od jej charakteru, skomplikowania i wysokości przedmiotu sporu. W wyniku reformy sędzia zyskał szereg uprawnień dyskrecjonalnych w zakresie ustalania stanu faktycznego ${ }^{68}$. W literaturze przedmiotu pojawił się pogląd, że zmiany przeprowadzone a angielskim postępowaniu cywilnym w $1999 \mathrm{r}$. spowodowały „wypatroszenie kontradyktoryjnego systemu" ${ }^{\prime \prime}$.

IV. W kręgu prawa socjalistycznego, pod którego wpływem pozostawały państwa Europy Środkowej, wzorcowym dla wszystkich socjalistycznych procedur cywilnych było prawo radzieckie. Postępowanie cywilne w ZSRR kodyfikowane było dwukrotnie. W obu przypadkach kodyfikacja radzieckiego postępowania cywilnego przypadała na czasy liberalizacji politycznej. Pierwszy kodeks RSFRR $(1923)^{70}$ pochodził z okresu rozluźnienia polityki władz radzieckich w dziedzinie gospodarczej w związku z przyjęciem ograniczonej formy gospodarki rynkowej. Drugi kodeks postępowania cywilnego RSFRR (1964) ${ }^{71}$ powstał w ramach ogólnej poststalinowskiej rekodyfikacji prawa radzieckiego, przeprowadzonej w latach 1954-1964, kiedy zarysowała się ogólna tendencja do usystematyzowania materiału prawnego ${ }^{72}$.

Socjalistyczna procedura cywilna była szybka, co wzbudzało duże zainteresowanie Zachodu ${ }^{73}$. Dynamiczny rozwój zainteresowania prawem radzieckim przypadał już na czasy poststalinowskie. Zmiana klimatu politycznego w ZSRR, która skutkowała także liberalizacją w prawie, sprzyjała podjęciu szczegółowych studiów nad prawem socjalistycznym nie ukierunkowanych już wyłącznie na jego wymiar ideologiczny ${ }^{74}$. Radzieckie akty prawne w zakresie postępowania cywilnego tłumaczono na język angielski ${ }^{75}$.

${ }^{68}$ R. Verkerk, England and Wales. (Powers of the judge), [w:] European Traditions in Civil Procedure..., s. 310. Zob. też P. Rylski, Działanie sądu z urzędu..., s. 146-147.

${ }^{69}$ J.A. Jolowicz, On Civil Procedure, Cambridge 2000, s. 286.

${ }^{70}$ A. Stawarska-Rippel, O pierwszym radzieckim kodeksie procedury cywilnej. Postepowanie cywilne od dekretów o sądzie do poczatków rekodyfikacji radzieckiego prawa, [w:] O prawie i jego dziejach księgi dwie. Studia ofiarowane Profesorowi Adamowi Lityńskiemu w czterdziestopięciolecie pracy naukowej i siedemdziesięciolecie urodzin, komitet red.: J. Ciągwa M. Mikołajczyk, P. Fiedorczyk, A. Stawarska-Rippel, T. Adamczyk, A. Drogoń, W. Organiściak, Białystok-Katowice 2010, t. 2, s. 335-366.

${ }^{71}$ A. Stawarska-Rippel, O rekodyfikacji radzieckiego postępowania cywilnego, „Z Dziejów Prawa" t. 4 (12), pod red. A. Lityńskiego, M. Mikołajczyka, W. Organiściaka, Katowice 2011, s. $187-202$.

${ }^{72}$ H. Berman, Justice in the U.S.S.R. An Interpretation of Soviet Law, Harvard University Press, wyd. 5, 1978, s. 69-70.

${ }^{73}$ Encyclopedia of Comparative Law, vol. XVI Civil Procedure, ch. 1 Introduction - Policies, Trends and Ideas in Civil Procedure..., s. 12-13.

${ }^{74}$ F.J.M. Feldbrugge, The Study of Soviet Law (tekst wystąpienia z 16 sierpnia 1978 r. otwierającego międzynarodową konferencję poświęconą radzieckiemu prawu, w 25. rocznicę powstania ośrodka dokumentacji prawa państw Europy Wschodniej), 4 „Review Socialist Law” 1978, nr 3, s. 201.

${ }^{75}$ Kodeks postępowania cywilnego z 1923 r. przetłumaczono na język angielski w 1949 r.: Soviet Civil Law, vol. II, translated by V. Gsovski, Ann Arbor 1949; Zasady ustawodawstwa w za- 
Trudności w analizie radzieckiego prawa, w tym prawa postępowania cywilnego potęguje to, że nie jest łatwe ustalenie rzeczywistej praktyki stosowania jego norm. Funkcjonowanie w praktyce wielu nieformalnych wytycznych w Rosji radzieckiej i ZSRR rzutuje negatywnie na możliwość rzetelnej oceny poszczególnych instytucji prawa socjalistycznego. Zakres rozbieżności pomiędzy prawem „na papierze” a rzeczywistością wydaje się wręcz niemożliwy do ustalenia ${ }^{76}$. W zakresie radzieckiego postępowania cywilnego poczyniono jednak w pewnym zakresie badania empiryczne ${ }^{77}$, które wskazują na stosunkowo krótki czas rozpoznawania spraw cywilnych ${ }^{78}$. Trudno jednak ocenić w pełni wiarygodność tych ustaleń. Wyczerpujące statystyki i sprawozdania dotyczące spraw cywilnych nigdy nie zostały w Rosji radzieckiej opublikowane.

Położenie nacisku na interes kolektywny, czy interes publiczny ${ }^{79}$, w socjalistycznym postępowaniu cywilnym determinowało treść zasad procedury

kresie postępowania w sprawach cywilnych z 8 grudnia 1961 r. przetłumaczono w 1963 r.: Soviet Civil Legislation and Procedure, Official text and Commentaries, transl. Y. Sudobnikov, Foreign Languages Publishing House, Moskva 1962. Zob. też Law in Eastern Europe. A series of publications issued by the Documentation Office for East European Law University of Leyden, No. 7, ed. Z. Szirmai, Leyden 1963. Kodeks postępowania cywilnego z 1964 r. został przetłumaczony na język angielski w 1966 r.: The Civil Code and the Code of Civil Procedure of the RSFSR 1964, translated by A.K.R. Kiralfy, Law in Eastern Europe. A series of publications issued by the Documentation Office for East European Law University of Leyden, No. 11, ed. Z. Szirmai, Leyden 1966.

${ }^{76}$ A. Lityński, Prawo Rosji i ZSRR 1917-1991, czyli historia wszechzwiazkowego komunistycznego prawa bolszewików. Krótki kurs. Warszawa 2010, s. 18. W kontekście postępowania cywilnego zwraca na ten aspekt uwagę D. Maleshin, Russian Style of Civil Procedure, „Emory International Law Review” 2007, vol. 21, s. 558.

${ }^{77}$ Badacz wymiaru sprawiedliwości Rosji radzieckiej zaobserwował stopniowy wzrost liczby spraw cywilnych w okresie NEP, co potwierdza stopniową normalizację sytuacji w dziedzinie gospodarki. Ta wzrostowa tendencja zarysowała się już w drugiej połowie $1920 \mathrm{r}$. W roku 1923 sądy rozpatrzyły ok. 1,4 mln spraw, w 1924 r. ok. 1,9 mln, w latach 1925-1927 ok. 3,8 mln, a w roku 1928 ok. 4,5 mln spraw. Należy zgodzić się z autorem przytoczonych danych, że istniało duże prawdopodobieństwo szybszego wzrostu spraw cywilnych, gdyby nie zmiany w prawie rodzinnym z 1926 r., które zlikwidowały rozpatrywanie spraw rozwodowych w drodze sądowej, przekazując je do trybu administracyjnego Kiedy w 1929 r. odchodzono już od polityki NEP i rozpoczęto przymusową kolektywizacji rolnictwa, liczba spraw cywilnych radykalnie spadła do ok. 1,5 mln. Dopiero w 1933 r. odnotowano stopniowy wzrost wpływu spraw cywilnych. W kolejnych latach liczba spraw się podwoiła, osiągając poziom ok. 7 mln w $1940 \mathrm{r}$. W latach 1941-1943 liczba spraw cywilnych w sądach stopniowo malała. W latach 50. sprawy cywilne w sądach osiągnęły pułap ok. $4 \mathrm{mln}$. Lata 60. to okres stabilizowania się liczby spraw cywilnych na poziomie ok. $3 \mathrm{mln}$. G.P. Van den Berg, The Soviet System of Justice: Figures and Policy, Leiden 1985, s. 143. Zob. też idem, Sovjet-Staat En Recht in Beweging. Inleiding, Grondrechten En Staatsinstellingen. Nijmegen 1991. G.P. Van den Berg jest współredaktorem, obok F.J.M. Feldbrugge i W.B. Simonsa, pracy Encyclopedia of Soviet Law, Leiden 1985.

${ }^{78}$ Encyclopedia of Comparative Law, vol. XVI Civil Procedure, ch. 1, Introduction - Policies, Trends and Ideas in Civil Procedure..., s. 13.

${ }^{79}$ Art. 2 radzieckiego k.p.c. z 1964 r.: „Celami radzieckiej procedury cywilnej są właściwe i szybkie postępowanie ochraniające porządek publiczny i ustrój ZSRR, socjalistyczny ustrój gospodarczy, socjalistyczną własność, polityczne, socjalne i inne osobiste i gospodarcze prawa oby- 
cywilnej. Zasady publiczności i edukacyjnej roli procedury cywilnej wymagały koncentracji postępowania, tym samym jej przyspieszenia. Sprawności radzieckiej procedury cywilnej służyło też stadium zwane przygotowaniem przed rozprawą (подготовка), by orzec w sprawie w jak najkrótszym czasie. Zarówno rosyjskie przedrewolucyjne postępowanie cywilne, jak i radzieckie w kodeksach z 1923 i 1964 r. ${ }^{80}$ dużą wagę przywiązywało do tzw. czynności wstępnych. Strony winne były przedstawić cały materiał dowodowy na pierwszym posiedzeniu sądu, co miało sprzyjać ekonomii procesowej. Niedopełnienie tego wymogu narażało stronę na zapłacenie grzywny, gdyby w następstwie późniejszego, stopniowego, przedstawiania dowodów wynikała zwłoka w rozpatrzeniu sprawy. Przedstawienie dowodów przez strony w czasie publicznej rozprawy mogło się odbyć tylko na podstawie decyzji sędziego. Znawca przedmiotu wyraził pogląd, że w obliczu uprawnień sędziego $\mathrm{w}$ ramach tzw. czynności wstępnych, w istocie publiczna rozprawa była przewidywalną ${ }^{81}$.

Radziecka procedura cywilna charakteryzowała się szerokim uwzględnieniem zasady ustności, co czyniło ją dostępną dla obywatela. W literaturze przedmiotu zauważono, że udział ławników w postępowaniu cywilnym dodatkowo przemawiał za ustną a nie pisemną procedurą ${ }^{82}$.

Instytucją mającą przeciwdziałać przewlekaniu postępowania jest klauzula nadużycia praw procesowych ${ }^{83}$. W tym kontekście stosunkowo wcześnie na tle procedur cywilnych państw Europy kontynentalnej było pojawienie się w radzieckim kodeksie postępowania cywilnego z 1923 r. konstrukcji nadużycia prawa ${ }^{84}$. W nieco zmienionej i bardziej ogólnej formule została

wateli i ich prawnie chronione interesy, a także prawa i prawnie chronione interesy państwowych instytucji, przedsiębiorstw, kołchozów i innych organizacji publicznych. Procedura cywilna powinna wzmacniać socjalistyczną praworządność, edukować obywateli w duchu zasad radzieckiego prawa i poszanowania reguł socjalistycznego współżycia" (tłum. moje - A. S-R) Гражданский прочессуальный кодекс РСФСР от 11 июня 1964 г. „Ведомости Верховного Совета РСФСР” 1964, nr 24, poz. 407.

${ }^{80}$ Art. 80 k.p.c. RSFRR z 1923 r.; art. 33 ustawy Об утверждении Основ гражданского судопроизводства Союза ССР и союзных республик от 8 декабря 1961 года, „Ведомости Верховного Совета СССР”, 1961, nr 50, poz. 525; art. 141-143 k.p.c. RSFRR z 1964 r.

${ }^{81}$ D.W. Chenoweth, Soviet Civil Procedure. History and Analysis, Philadelphia 1977, s. 24.

${ }^{82}$ Encyclopedia of Comparative Law, vol. XVI Civil Procedure, ch. 1, Introduction - Policies, Trends and Ideas in Civil Procedure..., s. 13.

${ }^{83}$ T. Ereciński, O uwarunkowaniach, potrzebie oraz zakresie nowego kodeksu postepowania cywilnego, „Polski Proces Cywilny”, 2010, nr 1, s. 13. Zob. też Abuse of procedural rights: comparative standards of procedural fairness, 27-30 October 1998, ed. M. Taruffo, Tulane Law School, New Orleans, Louisiana 1999.

${ }^{84}$ Art. 6 radzieckiego k.p.c. z 1923 r.: ,,Strony są zobowiązane w dobrej wierze wykorzystywać przynależne im prawa procesowe. Wszelkie nadużycia i oświadczenia mające na celu przeciąganie i zaciemnienie procesu będą natychmiast stłumione (przerwane) przez sąd" (tłum. moje - A. S-R). [Wcześniej, w art. 10 projektu pierwszego radzieckiego k.p.c., sformułowano obowiązek wykorzystania przez strony procesu wszystkich praw proceduralnych im przynależnym, lecz tylko w dobrej wierze. Sąd był zobowiązany do usunięcia każdego działania stron mającego na celu opóźnienie 
uwzględniona również w Zasadach ustawodawstwa w zakresie postępowania w sprawach cywilnych z 1961 r. oraz w radzieckim k.p.c. z 1964 r. ${ }^{85}$ Obecnie obowiązujący rosyjski k.p.c. z 2002 r. utrzymał konstrukcję nadużycia prawa ${ }^{86}$.

$\mathrm{Z}$ interesem publicznym na gruncie postępowania cywilnego wiąże się zagadnienie poszukiwania $\mathrm{w}$ procesie cywilnym prawdy materialnej (obiektywnej). W zakresie ograniczania zasady kontradyktoryjności oraz dążenia do osiągnięcia prawdy materialnej i elementów śledczych w procesie cywilnym, radzieckie regulacje nie odbiegały w znaczący sposób od ogólnej tendencji zmian w postępowaniu cywilnym państw Zachodniej Europy ${ }^{87}$. Radzieckie postępowanie cywilne wyróżniało się natomiast daleko idącym ograniczeniem zasady dyspozycyjności, która w procesie cywilnym państw spoza kręgu prawa socjalistycznego doznaje ograniczeń tylko w wyjątkowych przypadkach. Zasada ne eat iudex ultra petita partium została zastąpiona w radzieckim postępowaniu cywilnym zasadą ex offico ultra petita. Była to nowość charakteryzująca procedurę cywilną w państwach totalitarnych.

Poglądy o specyficznym i unikatowym charakterze radzieckiego prawa postępowania cywilnego dotyczą szczególnej roli sędziego w postępowaniu dowodowym, roli prokuratora w procesie, nadzór sądowy (rewizję nadzwyczajną) i szczególny status sądowego orzecznictwa ${ }^{88}$. Zachodni komparatyści wskazują jednak, że pewne elementy radzieckiego postępowania cywilnego były historycznie zakorzenione w przeszłości ${ }^{89}$ i stanowiły jedynie pewną postać podobnych rozwiązań w postępowaniu sądowym społeczeństwa otwarte$\mathrm{go}^{90}$. Dostrzeżono także pewne podobieństwa w zakresie warunków, w jakich kształtowała się instytucja francuskiej kasacji w interesie prawa - cassation

albo nadużycie procedur, jednocześnie strony miały być pozbawione prawa do używania uprawnień proceduralnych na przyszłość. W toku prac zrezygnowano jednak z możliwości pozbawienia stron nadużywających swoich praw z uprawnień procesowych na przyszłość.] J.N. Hazard, Settling Disputes in Soviet Society. The Formative Years of Legal Institutions, New York 1978, s. 399.

${ }^{85}$ Art. 24 ustawy Об утверждении Основ гражданского судопроизводства Союза ССР и союзных республик от 8 декабря 1961 года, „Ведомости Верховного Совета СССР”, 1961, $\mathrm{nr} 50$, poz. 525: ,[...] strony zobowiązane są do sumiennego korzystania z przynależnych im praw proceduralnych”. Art. 30 radzieckiego k.p.c. z 1964 r.: ,,[...] Osoby biorące udział w sprawie zobowiązane są do korzystania $\mathrm{z}$ wszystkich należnych im praw procesowych w dobrej wierze".

86 Art. 35 rosyjskiego k.p.c. z 2002 r.: ,[...] Osoby biorące udział w sprawie zobowiązane są do korzystania ze wszystkich uprawnień procesowych w dobrej wierze". Гражданский процессуальный кодекс Российской Федерации от 14 ноября 2002, „Собрание законодательства РФ”, 2002, nr 46, poz. 4532.

${ }^{87}$ K. Grzybowski, Soviet Legal Institutions. Doctrine and Social Functions, The University of Michigan Press, Ann Arbor 1962, s. 105.

${ }^{88}$ D. Maleshin, Russian Style of Civil Procedure..., s. 547.

${ }^{89}$ A.W. Rudziński [w:] L. Boim, G.G. Morgan, A.W. Rudziński, Legal Controls in the Soviet Union. Law in Eastern Europe. A series of publications issued by the Documentation Office for East European Law University of Leyden, No. 13, ed. Z. Szirmai, Netherlands 1966, s. 287-338.

${ }^{90}$ K. Grzybowski, Soviet Legal Institutions. Doctrine and Social Functions..., s. 105. 
dans l'intérêt de la loi i kasacji z powodu nadużycia władzy - cassation pour excès de pouvoir ${ }^{11}$, oraz radzieckiego prokuratorskiego nadzoru sądowego, w drodze którego prokurator mógł złożyć protest (skargę nadzorczą) od prawomocnych wyroków sądowych ${ }^{92}$. Zarówno francuska kasacja, jak i radziecki nadzór sądowy były związane $\mathrm{z}$ działalnością prokuratora, były środkiem kontroli prawomocnych orzeczeń sądu i wyrosły na tle braku zaufania do sądów i sędziów. Instytucję podobną do późniejszego radzieckiego nadzoru sądowego przewidywała berneńska procedura cywilna (1918) (Kassation von Amtes wegen). Sąd Apelacyjny jako Najwyższy Sąd kantonu mógł unieważnić prawomocne orzeczenie działając ex officio w przypadku, gdy zostały naruszone zasady procedury cywilnej lub gdy sąd był niewłaściwy w sprawie, a wydanie zgodnego z prawem orzeczenia (Beurteilung) było niemożliwe albo bardzo utrudnione. Berneńska kasacja ex officio znalazła się wśród naczelnych zasad postępowania sądowego i nie stanowiła instytucji służącej stronom w postępowaniu. Ani limit czasowy, ani inicjatywa stron nie ograniczały Najwyższego Sądu kantonu berneńskiego w sprawie przeprowadzenia kasacji ex officio. Ta szwajcarska instytucja bazowała na prawie najwyższego sądu w kantonie do nadzoru nad działalnością sądów niższych (Aufsichtsrecht). W praktyce jednak była niezmiernie rzadko wykorzystywana ${ }^{93}$.

Radzieckie postępowanie cywilne było specyficznym połączeniem socjalistycznej praworządności i pewnych elementów europejskiej tradycji z odrobiną dawnego przedrewolucyjnego prawnego dziedzictwa rosyjskiego ${ }^{94}$. Reforma postępowania cywilnego w okresie pieriestrojki (1995) przywróciła, aczkolwiek na krótko, ściśle kontradyktoryjny charakter procedury cywilnej ${ }^{95}$. Obecnie obowiązujący w Rosji kodeks procedury cywilnej uwzględnia ponownie w pewnym zakresie elementy zasady inkwizycyjnej, wpisując się W ogólną tendencję rozwoju postępowania cywilnego ${ }^{96}$.

${ }^{91}$ P. Herzog, M. Weser, Civil Procedure in France. Columbia University School of Law Project on International Procedure, direct. and ed. by H. Smith, Netherlands 1967, s. 123 i nast. Zob. też A. Stawarska-Rippel, Radziecka procedura cywilna: totalitarna czy nowoczesna, [w:] Studia nad faszyzmem i zbrodniami hitlerowskimi, t. XXXIII, Polskie interpretacje totalitaryzmu i autorytary$z m u$, pod red. M. Maciejewskiego i M. Marszała, Wrocław 2011, s. 467-479.

${ }^{92}$ A. Lityński, Prawo Rosji i ZSRR 1917-1991..., s. 321.

${ }^{93}$ Art. 90 procedury cywilnej berneńskiej z 7 czerwca 1918 r.: Kassation von Amtes wegen 1. Der Appellationshof ist befugt, ein Prozessverfahren, in welchem wesentliche Grundsätze des Verfahrens derart verletzt worden sind, dass die richtige Beurteilung unmöglich oder wesentlich erschwert wird, von Amtes wegen aufzuheben. Ebenso kann ein Entscheid oder eine Verfügung einer untern Gerichtsbehörde aufgehoben werden, wenn sie zu deren Erlass offensichtlich sachlich nicht zuständig war. 2. Bei grobem Verschulden oder Arglist sind die Kosten den fehlbaren Gerichtspersonen, Parteien oder Anwälten aufzuerlegen. Zob. też A.W. Rudziński, [w:] L. Boim, G.G. Morgan, A.W. Rudziński, Legal Controls in the Soviet Union. Law in Eastern Europe..., s. 296.

${ }^{94}$ Por. G.B. Smith, Reforming the Russian Legal System, Cambridge 1996, s. 139.

${ }^{95}$ D. Maleshin, Russian Style of Civil Procedure..., s. 546.

${ }^{96}$ Por. D. Maleshin, Russian Style of Civil Procedure..., s. 558. 
V. W państwach demokracji ludowej po przełomowym roku 1948 rozpoczęto proces obowiązkowej recepcji wzorców radzieckich. Zasadnicze zmiany w procedurze cywilnej tych krajów przypadały zazwyczaj na początek lat pięćdziesiątych. Czechosłowacja, Węgry, Jugosławia i Bułgaria posiadały już wówczas nowe kodeksy procedury cywilnej ${ }^{97}$. Wyjątkiem była Rumunia Polska i NRD ${ }^{98}$. Obowiązujący w Rumunii kodeks postępowania cywilnego z 1865 r., wzorowany na francuskim kodeksie procedury cywilnej z 1806 r. i kodeksie szwajcarskiego kantonu Genewy z 1819 r., przetrwał okres państwa ludowego, choć po $1945 \mathrm{r}$. był poddawany licznym zmianom ${ }^{99}$. W NRD do 1975 r. obowiązywał kodeks procedury cywilnej z 1877 r. po zasadniczych zmianach z 8 listopada 1933 r. Po drugiej wojnie światowej nowelizowany był trzykrotnie, w latach 1952, 1956 i $1973^{100}$.

W Polsce przejęty formalnie, aczkolwiek wybiórczo, względnie i krytycznie, porządek prawny Drugiej Rzeczypospolitej poddano gruntownej przebudowie w latach 1949-1950101. Zasadnicze nowości o charakterze socjalistycznym pojawiły się w postępowaniu cywilnym w ustawie z 20 lipca 1950 r. $^{102}$, zmieniającej kodeks postępowania cywilnego z 1932 r. Przed 1950 r., będącym przełomowym ze względu na zakres i charakter zmian w obowiązującym prawie, wprowadzono szereg nowych regulacji w zakresie postępowania cywilnego, które w ówczesnej literaturze przedmiotu scharakteryzowano jako zmiany techniczno-porządkowe oraz ogólnodemokratyczne ${ }^{103}$.

Zwiększenie kontroli sądu nad czynnościami podejmowanymi przez strony, dopuszczenie orzekania ponad żądanie oraz szerokie uprawnienia pro-

${ }^{97}$ E. Wengerek, [w:] Encyclopedia of Comparative Law, vol. XVI, Civil Procedure, ch. 1, Introduction - Policies, Trends and Ideas..., s. 141-151.

${ }^{98}$ C. Tabęcki, Dowody i dowodzenie wedhug socjalistycznych procedur cywilnych, NP 1955, nr 7-8, s. 18,30 .

${ }^{99}$ K.p.c. rumuński z 1865 r. zmieniany był w okresie trwania państwa socjalistycznego w latach: 1948, 1950, 1952, 1957 i 1969. E. Wengerek, [w:] Encyclopedia of Comparative Law, vol. XVI, Civil Procedure, ch. 1, Introduction - Policies, Trends and Ideas..., s. 144.

${ }^{100}$ Ibidem, s. 142.

${ }^{101}$ A. Lityński, Historia prawa Polski Ludowej, Warszawa 2010, s. 34; A. Stawarska-Rippel, Prawo sadowe Polski Ludowej 1944-1950 a prawo Drugiej Rzeczypospolitej, Katowice 2006, s. 33-60.

${ }^{102}$ Dz. U. nr 38, poz. 349 - tj. Dz. U. nr 43, poz. 394.

${ }^{103}$ W. Berutowicz, Charakter zmian prawa i postepowania cywilnego w Polsce Ludowej, „Zeszyty Naukowe Uniwersytetu Wrocławskiego", Seria A, Prawo, t. III, Wrocław 1958, s. 207. Autor szczegółowo omawia wprowadzone w latach 1944-1950 zmiany prawa postępowania cywilnego. Ważne były zwłaszcza: dekret z 18 lipca 1945 r. - Kodeks postępowania niespornego; ustawa z 27 kwietnia 1949 r. o zmianie niektórych przepisów postępowania cywilnego, prawa upadłościowego oraz przepisów wprowadzających prawo małżeńskie (Dz. U. Nr 32, poz. 240) wprowadzająca laicyzację postępowania cywilnego przez zniesienie przysięgi i zastąpienie jej świecką formą przyrzeczenia mówienia prawdy oraz znosząca pochodne określenie właściwości miejscowej sądu kobiety zamężnej od miejsca zamieszkania męża; oraz ustawa z 27 czerwca 1950 r. o postępowaniu niespornym w sprawach rodzinnych oraz zakresu kurateli (Dz. U. Nr 34, poz. 310). Wprowadzająca ograniczenie rozporządzalności stron oraz orzekanie na zasadzie prawdy obiektywnej. 
kuratora w postępowaniu cywilnym były nowościami o charakterze socjalistycznym, w różnym stopniu recypowanymi w krajach demokracji ludowej. Pierwszym i zarazem najbardziej zbliżonym do radzieckiego modelu był czechosłowacki kodeks postępowania cywilnego (1950). Na nim wzorowano się bezpośrednio podczas pierwszego etapu prac (1951-1955) nad nowym kodeksem postępowania cywilnego w Polsce Ludowej ${ }^{104}$.

Tempo prac nad nowym, socjalistycznym prawem w Czechosłowacji było imponujące, zwłaszcza że stała się ona częścią bloku radzieckiego dopiero w 1948 r. ${ }^{105}$ Od 7 grudnia 1949 do 12 lipca 1950 r. uchwalono w Czechosłowacji kodeksy: rodzinny ${ }^{106}$, cywilny ${ }^{107}$, postępowania cywilnego ${ }^{108}$, a także karny $^{109}$ i postępowania karnego ${ }^{110}$.

Demokratyzacja postępowania cywilnego w Czechosłowacji wyrażała się zwłaszcza w ograniczeniu zasady dyspozycyjności na rzecz zasady oficjalności. Dotychczasowe pojęcia: „wniesienie pozwu” i ,skarga” zastąpiono w czechosłowackiej ustawie nowym terminem - ,wniosek o wszczęcie postępowania"111. Postępowanie cywilne inicjowane było na wniosek lub z urzędu przez prokuratora, który mógł również na każdym etapie przystąpić do postępowania toczącego się z inicjatywy stron, korzystając z wszelkich praw przynależnym stronom ${ }^{112}$. „Interes państwa” i ,interes ludu pracującego”, będące wytyczną dla działania prokuratora na gruncie postępowania cywilnego, są przykładem charakterystycznej dla prawa socjalistycznego hipertrofii klauzul generalnych. Celem „wzmocnienia praworządności socjalistycznej” sąd miał obowiązek wszechstronnego wyjaśnienia faktycznych okoliczności sprawy, uzupełniony możliwością dopuszczenia z urzędu dowodów niepowołanych przez strony ${ }^{113}$. Podobnie stanowił węgierski kodeks procedury cy-

${ }^{104}$ AAN 2213 (1952), k. 3.

105 O socjalistycznej kodyfikacji w Czechosłowacji w latach 1948-1950 zob. P. Fiedorczyk, Czechosłowacka droga do kodyfikacji prawa rodzinnego (1919-1949), [w:] Państwo, prawo, społeczeństwo w dziejach Europy Środkowej. Księga jubileuszowa dedykowana Profesorowi Józefowi Ciagwie $w$ siedemdziesięciolecie urodzin, pod red. A. Lityńskiego, M. Mikołajczyka, T. Adamczyka, A. Drogonia, W. Organiściaka, Katowice-Kraków 2009, s. 187-189.

106 Zákon o právu rodinném. Sbírka zákonu ČR, č. 265/1949.

107 Občanský zákoník. Sbírka zákonu ČR, č. 141/1950.

108 Zákon o řizeni ve věcech občanskoprávních (občanský soudní řád). Sbírka zákonu ČR, č. $142 / 1950$.

109 Trestní zákon. Sbírka zákonu ČR, č. 86/1950

${ }^{110}$ Trestní zákon správní. Sbírka zákonu ČR, č.88/1950

111 T.J. Vondracek, A Commentary on the Czechoslovak Civil Code, „Law in Eastern Europe” vol. 37, Dordrecht, 1988, s. XXIV.

112 Zákon o řizení ve věcech občanskoprávních (občanský soudní řád). Sbírka zákonu ČR, č. $142 / 1950-\S 6$ i $\S 41(1)$.

113 K.p.c. czechosłowacki z 1950 r.: „§ 1 (2) W realizacji tych zadań sąd postępuje bez zbędnych formalności. Dba wszechstronnie o to, by określić rzeczywisty stan rzeczy, a sprawiedliwym orzecznictwem wzmacnia praworządność socjalistyczną i wychowuje obywateli do wypełniania obowiązków obywatelskich”; „§ 88 (2) Sąd powołuje dowody z własnej inicjatywy, niezależnie od 
wilnej z 1952 r. ${ }^{114}$, a także bułgarski kodeks procedury cywilnej z 8 lutego 1952 r. $^{115}$

Ograniczenie zasady kontradyktoryjności w procesie cywilnym mającym pełnić funkcję społeczną, zapewniając sprawiedliwe orzecznictwo zgodne z rzeczywistym stanem rzeczy, zakorzenione było już w kulturze prawnej Zachodu. Jednak w państwach demokracji ludowej, zwłaszcza w pierwszej dekadzie, prawo było zorientowane przede wszystkim politycznie. Było wykorzystywane do organizowania nowej struktury gospodarczo-społecznej, zdefiniowanej w zakresie jej politycznej funkcji i podporządkowane polityce władzy $^{116}$. Dyferencja własności i jej ochrony ${ }^{117}$, wprowadzenie planowej gospodarki skutkowało osłabieniem znaczenia cywilnego prawa procesowego na rzecz wzrostu znaczenia prawa administracyjnego, czego bezpośrednim wyrazem było funkcjonowanie państwowego arbitrażu gospodarczego ${ }^{118}$.

Uchwalenie nowego polskiego kodeksu postępowania cywilnego przypadało już na czas rekodyfikacji prawa w ZSRR w latach 1957-1965. Zmiany polityczne i rewizja założeń ideologicznych oraz pewna liberalizacja prawa w ZSRR umożliwiły podjęcie reform w państwach demokracji ludowej. Nowe kodeksy procedury cywilnej uchwalono w Czechosłowacji (1963), w NRD (1975) i Jugosławii (1976). Szeroko zakrojone reformy podjęto również na Węgrzech $(1972)^{119}$. Na tle wprowadzanych zmian rysowała się wyraźna tendencja do poprawy prawa procesowego i zwiększenia efektywności systemu sądowego ${ }^{120}$. Te wydarzenia wywarły korzystny wpływ na rozwiązania polskiego prawa postępowania cywilnego. Podczas gdy pierwszy projekt polskiego kodeksu cywilnego (1955) niweczył dotychczasowe osiągnięcia

inicjatywy stron, jeśli są one istotne dla rozstrzygnięcia" [tłum. moje - A. S-R] Zákon o rrizení ve věcech občanskoprávních (občanský soudní rád). Sbírka zákonu ČR, č. 142/1950.

114 Węgierski k.p.c. z 1952 r.: „§ 3 (1) Do zadań sądu jest zgodnie z celami tej ustawy (§ 1) należy dążenie do ujawnienia prawdy materialnej. [...] (2) Sąd z urzędu troszczy się o gruntowne a zarazem szybkie rozpoznanie spraw.”; „§ 164. Fakty sporne winna, z reguły, udowodnić strona, która interes wymaga, aby sąd przyjął je za prawdziwe. Niezależnie od tego sąd może z urzędu dopuścić dowód uznany przezeń za celowy”. Törvény a polgári perrendtartásról 1952. évi III. Polskie tłumaczenie węgierskiego kodeksu postępowania cywilnego - materiały kodyfikacyjne, AAN, sygn. 2227, 1952, k. 1 i k. 64.

${ }^{115}$ K.p.c. bułgarski z 1952 r.: „Art. 4: Sąd orzeka wyłącznie na podstawie prawa. Sąd aktywnie uczestniczy w pełnym wyjaśnieniu i ujawnianiu praw i wzajemnych relacji między stronami. Sąd pomaga stronom w wykonywaniu wymaganych prawem działań aby zapobiec szkodom w zakresie ich interesów spowodowanych nieznajomością prawa, analfabetyzmem lub z innymi przyczynami”; „Art. 129: Sąd może z urzędu powoływać dowody, jak również prowadzić dochodzenie w zakresie tych dowodów, które już zostały zebrane i przedstawione" [tłum. moje - A. S-R], Известия Бр, 12 от 8.02 .1952 г.

${ }^{116}$ P. De Cruz, Comparative Law in a Changing World..., s. 183-185.

${ }_{117}$ A. Machnikowska, Prawo własności w Polsce w latach 1944-1981, Gdańsk 2010, s. 87-98.

118 A. Stawarska-Rippel, Państwowy arbitraż w ZSRR, „Miscellanea Historico-Iuridica”, t. VII pod red. A. Lityńskiego i P. Fiedorczyka, Białystok 2009, s. 143-160.

${ }^{119}$ E. Wengerek [w:] Encyclopedia of Comparative Law..., s. 142.

${ }^{120}$ Ibidem, s. 146. 
polskiej nauki, które zlekceważono na rzecz szerokiego uwzględnienia socjalistycznych koncepcji, to dalsze prace nad postępowaniem cywilnym charakteryzowały się już dość dobrym poziomem merytorycznym. Przyczyniły się do tego zmiany polityczne i ciągłość nauki prawa cywilnego ${ }^{121}$.

W Polsce, po zmianach ustrojowych przełomu 1989 i 1990 r., nowelizacje kodeksu postępowania cywilnego są w dalszym ciągu przedmiotem dysku$\mathrm{sji}^{122}$. Początkowo skoncentrowano się na przywróceniu modelu kontradyktoryjnego, ograniczając uprawnienia sądu i wzmacniając aktywność stron, odchodząc jednocześnie od założeń prawdy materialnej. Celem tych nowelizacji miało być przede wszystkim usprawnienie postępowania cywilnego. W kontekście niniejszych rozważań symptomatyczna jest wypowiedź szwajcarskiego prawnika Marcela Strorme'a:

„Nie niszczcie, proszę, tego wszystkiego, co powstało w ciągu 50 lat, tak więc np. obowiązek pouczenia sędziego, ograniczenie środków prawnych, pomoc prawa dla słabych stron itp. Zniszczcie to wszystko, co charakteryzowało dyktatury występujące przeciwko niezawisłości sędziowskiej"123.

Komparatyści zauważyli, że naturalną tendencją po transformacji systemowej w państwach Europy Środkowej i Wschodniej jest bardzo wyraźne rozszerzanie autonomii stron. Wydaje się to reminiscencją przekonania, że państwo ingeruje w proces cywilny z powodów politycznych. Doświadczenia Zachodu i ewolucja prawa procesowego doprowadziły ostatecznie w większości państw zachodnich do przyjęcia modelu postępowania cywilnego z elementami śledczymi. Aktywne działanie sędziego w postępowaniu cywilnym postrzega się jako konieczne w związku z realizacją art. 6 Europejskiej Konwencji Praw Człowieka ${ }^{124}$. Równość, prawda i sprawiedliwość w kontekście rzetelnego procesu cywilnego wciąż pozostają tematem debaty ${ }^{125}$.

${ }^{121}$ A. Mączyński, Uwagi o stanie nauki polskiego prawa cywilnego, „Państwo i Prawo” 2011, nr 6, s. 6-8. Zob. też: M. Sawczuk, Tradycja a postęp w nowelizacji cywilnego prawa sądowego (in statu nascendi), Teka Komisji Prawniczej - Ol PAN, Lublin 2008, s. 168.

${ }^{122}$ T. Ereciński, O uwarunkowaniach, potrzebie oraz zakresie nowego kodeksu postępowania cywilnego..., s. 9-19. s. 170 .

123 Cyt. za M. Sawczuk, Tradycja a postęp $w$ nowelizacji cywilnego prawa sądowego...,

${ }^{124}$ C.H. van Rhee, Introduction..., s. 23. Zob. też T. Ereciński, O uwarunkowaniach, potrzebie oraz zakresie nowego kodeksu postępowania cywilnego..., s. 9-19.

${ }^{125}$ T. Pietrzykowski, B. Wojciechowski, Równość, prawda i sprawiedliwość w procesie cywilnym. Rozważania na tle nowelizacji k.p.c., „Palestra” 2004, z. 9-10, s. 11 i nast. 
ADVERSARIAL VS INQUISITORIAL TRIAL

IN THE EUROPEAN CIVIL PROCEDURE IN THE $19^{\text {th }}$ AND $20^{\text {th }}$ CENTURY

\section{Summary}

Socialisation of private law in the second half of the $19^{\text {th }}$ century brought about a new approach to a civil process and its purpose. The main characteristics of the evolution of the civil procedure in the $19^{\text {th }}$ and $20^{\text {th }}$ centuries was limited autonomy of the parties to a process. This limitation was introduced to ensure fair, expedient and cost-effective judgment. A tendency to replace the principle of an adversarial trial with elements of an inquisitorial trial was observed in civil law as well as common law systems. Relevant changes were first made in the Franz Klein Austrian code of civil procedure, followed by departures from the formal truth in the civil process implemented in the system in Germany, Hungary, the Swiss cantons of Zurich and Bern, in Poland, and later, in the second half of the $20^{\text {th }}$ century, also in France. In the common law system, the reform of 1999 ascertained judges a number of discretionary powers to help them establish the facts in a civil proceeding. Those changes added the public element in the civil procedure, but the very idea of a private process and the protection of private interests has been maintained. The totalitarian regimes which emerged in some European states considerably distorted the process of shaping the relationship between the state and the individual. In the socialist civil proceeding, the principle ne eat iudex ultra petita partium was replaced with ex officio ultra petita, which was a novelty characteristic of the civil procedure of totalitarian states. The departure from an adversarial principle in the socialist civil process was not much different from the general tendencies observed in the civil procedure in West European states. After the political transformations and change of the regime, former states of the Eastern Bloc sought to significantly increase the autonomy of the parties in a civil process. However, as experience of the Western European states shows, certain public elements must be taken into account in a civil procedure if the European Convention on Human Rights is to be observed.

\section{LES PRINCIPES DU CONTRADICTOIRE ET CEUX D'INQUISITION DANS LA PROCÉDURE CIVILE EUROPÉENNE AUX XIX ${ }^{\mathrm{e}}$ ET XX $\mathrm{X}^{\mathrm{e}}$ SIÈCLES}

\section{Résumé}

Le phénomène de la socialisation du droit privé pendant la deuxième moitiée du XIX ${ }^{e}$ siècle aura pour effet l'apparition d'une nouvelle vision du procès civil. Le trait caractéristique de l'évolution de la procédure civile au $\mathrm{XIX}^{\mathrm{e}}$ et $\mathrm{XX}^{\mathrm{e}} \mathrm{s}$. est la restriction de l'autonomie des parties afin de maintenir des valeurs telles que jurisprudence équitable dans un procès civil rapide mais à la fois avantageux économiquement parlant. Les tendences à limiter le principe du contradictoire à travers les 
éléments d'inquisition apparaissent dans les deux familles du droit: civil law et common law. Concernant le domaine du civil law, la vérité formelle dans le procès civil est petit à petit abandonnée, d'abord dans le code autrichien de la procédure civile de Franz Klein, ensuite en Allemagne et en Hongrie, dans les cantons suisses de Zurich et de Bern ainsi qu'en Pologne. La France, elle aussi suit cette tendence pendant la deuxième moitié du $\mathrm{XX}^{\mathrm{e}}$ siècle. En ce qui concerne par contre le common law, suite à la réforme anglaise de 1999, le juge obtient de nombreux pouvoirs discrétionnaires en matière de l'établissement de l'état de fait dans une procédure civile. Mais avoir pris en compte de manière assez importante l'élément public dans la procédure civile, n'enlève pas au procès civil sa quintessence. Il doit servir à la protection des intérêts privés. La naissance des régimes totalitaires en Europe perturbera l'évolution des relations entre l'individu et l'État. Dans la procédure civile socialiste, la principe ne eat iudex ultra petita partium est remplacé par les règles ex offico ultra petita. A l'époque, c'est une nouveauté, une particularité de la procédure civile dans les pays totalitaires. Et le principe du contradictoire restreint dans le procès civil socialiste ne s'éloigne pas trop des tendences générales relatives aux changements survenus au sein de la procédure civile en Europe Occidentale. En ce qui concerne les anciens pays de la démocratie populaire, après les transformations du système, ils vont viser un élargissement considérable de l'autonomie des parties. L'expérience de l'Occident nous montre toutefois que, dans une procédure civile, il est nécessaire de prendre en compte les éléments publics, notamment dans le contexte de la réalisation de la Convention européenne des Droits de l'Homme. 